\title{
The Expensive Truth: The Possible Tax Implications Related to Scholarship and Cost of Attendance Payments for Athletes
}

Patrick Michael Tutka

Niagara University

\section{Dylan Williams}

University of Alabama

\begin{abstract}
The result from O'Bannon v. NCAA should provide NCAA student-athletes with unprecedented financial benefits such as cost of attendance (COA) scholarships. While these benefits will support student-athletes, there are potential unintended consequences surrounding the increase in financial support, including federal and state income taxes. Athletic scholarships have traditionally been classified as qualified scholarships under Revenue Ruling 77-263. However, by providing a COA payment, the scholarship transforms from an educational benefit to a quid pro quo contractual agreement. As such, student-athletes may be forced to pay income taxes on their disqualified scholarship. The purpose of this study is to determine the potential taxability of the COA qualified scholarships. This study analyzes the Internal Revenue Code and Treasury Regulations to determine if the COA scholarship meets the requirements for a qualified scholarship. In addition, the present work provides potential tax implications for student-athletes receiving COA scholarships at both the federal and state levels.
\end{abstract}

Keywords: student-athletes, athletic scholarships, income taxation

Traditionally, National Collegiate Athletic Association (NCAA) member schools award scholarships to their student-athletes covering expenses related to tuition, fees, books, and meal plans. Following a protracted debate and a decision by the Ninth Circuit Court of Appeals (O'Bannon v. NCAA, 2015), institutions affiliated within Division I agreed to modify their scholarship offerings to provide the full cost of attendance (COA) to student-athletes to enroll at their schools to help them cover rudimentary expenses related to being a student. However, the $O$ 'Bannon v. NCAA ruling has major ramifications for the NCAA, its member institutions, and the compensation provided to student-athletes. Specifically, the traditional relationship between student-athletes and their universities could transform the matter in which the Internal Revenue Service (IRS) classifies scholarship income (Sanserino, 2014).

Tutka is with the College of Hospitality and Tourism Management, Niagara University, Niagara, NY. Williams is with the Dept. of Kinesiology, University of Alabama, Tuscaloosa, AL. Please address author correspondence to Patrick Tutka at ptutka@niagara.edu 
Internal Revenue Code (IRC) Section (\$) 61(a) (2006a) states the income of all individuals is subject to taxation regardless of the source derived. However, IRC $\$ 117$ (2006b) excludes from gross income money received in the form of a qualified scholarship. Conversely, $\$ 117$ (c) limits this exclusion if the money received from the scholarship represents a payment for teaching, research, or other services a student may perform as a condition for receiving the scholarship. Although O'Bannon has been beneficial to student-athletes, the requirement to pay up to COA has unintended and substantial tax implications. The purpose of this study is to determine the potential taxability of COA scholarships. This study analyzes the IRC and all related Treasury Regulations to determine if a COA scholarship meets the requirements for a nontaxed qualified scholarship. The present work also discusses the potential implications for student-athletes if any scholarship funding as well as additional compensation received for their duties as student-athletes were to be subject to taxation.

\section{O'Bannon v. NCAA Impact}

Over the last several decades, the NCAA has worked with its member institutions in attempts to establish a balanced playing field of college athletics (Tutka, 2016; Williams \& Seifried, 2013). These attempts include control of coach salaries (Law v. NCAA, 1998), broadcast rights of college football (NCAA v. Board of Regents, 1984), and limits to student-athlete stipends (O'Bannon v. NCAA, 2014, 2015). Each of these situations faced scrutiny from the Federal Court system in relation to antitrust issues. While the television and coaching-related issues have been decided, issues regarding student-athlete compensation are new and have significant importance to the current state of intercollegiate athletics.

O'Bannon v. NCAA began as an attempt to limit the NCAA's ability to use student-athlete likenesses in perpetuity based on the scholarship agreement between the student-athlete and its member institutions (Lodge, 2016). Former UCLA basketball player Ed O'Bannon and 19 other former football and basketball studentathletes filed a class action antitrust lawsuit against the NCAA, believing the NCAA was wrongfully profiting from the sale of the players' images and likenesses in EA Sports video games without providing compensation (O'Bannon v. NCAA, 2014). To counter, the NCAA contended that each student-athlete's scholarship agreement provided the organization the right to sell each athlete's image or likeness to a third party, and any compensation provided to athletes for their likenesses would undermine the principle of amateurism.

On August 8, 2014, District Judge Claudia Wilken ruled the NCAA violated the Sherman Antitrust Act as its rules and bylaws restrained free trade (O'Bannon $v$. $N C A A, 2014)$. The court held that the NCAA was in violation of antitrust litigation due to its decision to limit universities from providing the full cost of attendance to student-athletes, prompting anticompetitive actions and unreasonable restraints of trade. Judge Wilken ordered NCAA member schools to offer full COA scholarships to athletes, covering living expenses above tuition, fees, and related educational expenditures. Judge Wilken also ruled that the NCAA member schools should establish trust funds for all student-athletes and provide up to $\$ 5,000$ for each athlete's playing season starting in 2016 from money generated by its television 
contracts (O'Bannon v. NCAA, 2014). These trust funds would be held in deferment until the student-athlete's graduation from college.

The NCAA appealed the district court decision to the Ninth Circuit Court of Appeals, asking the court to examine the lower-court decision through facts established in NCAA v. Board of Regents (Berkowitz, 2015). The NCAA believed it was provided protections from antitrust litigation due to its need to protect amateurism (O'Bannon v. NCAA, 2015). Conversely, the Ninth Circuit found that the NCAA v. Board of Regents decision did not provide the NCAA complete protection from antitrust actions, arguing the NCAA was in violation of the "Rule of Reason" analysis and preventing athletes from competitively controlling the price of the rights to their likenesses. Furthermore, the Ninth Circuit affirmed the lower court decision regarding the violation of antitrust law since the NCAA did not allow its member universities to offer full COA scholarships to student-athletes. However, the appeals court disagreed with Judge Wilken's establishment of a $\$ 5,000$ per year requirement, arguing that any funding above COA would violate the concept of amateurism (O'Bannon v. NCAA, 2015). The majority opinion argued that paying student-athletes for noneducational services would erode amateurism over time and become a form of minor league professional sport. Thus, the NCAA was only required to allow schools to offer full COA scholarships to student-athletes. In May 2016, both the NCAA and the O'Bannon plaintiffs have asked the U.S. Supreme Court for an appeal of the Ninth Circuit decision, but they were denied it (Berkowitz \& Perez, 2016).

\section{NCAA Division I Autonomy}

Concurrent with the O'Bannon district court decision, the NCAA was also under tremendous pressure from some of its members as schools affiliated with the Atlantic Coast Conference, Big Ten Conference, Big XII Conference, Pacific-12 Conference, and Southeastern Conference as well as the independent University of Notre Dame (i.e., the Power Five schools) made overtures to NCAA leadership about leaving the association (Ellis, 2014). The Power Five members were contemplating departing the NCAA to start their own organization, which would alter the student-athlete classification. Faced with this threat, the NCAA Board of Directors approved a restructuring plan that would provide these institutions with greater autonomy in decision making (Weaver, 2015). As such, these 65 schools possess the ability to craft legislation affecting only themselves and not all other NCAA members (Bennett, 2014).

The autonomy group is composed of individuals from all 65 institutions as well as 15 student-athlete representatives (three from each member conference; Hosick, 2014). This collective has the ability to adopt rule changes on specific matters affecting the interests of student-athletes, such as legislation on the permissive use of resources and the well-being of student-athletes (Bennett, 2014). The NCAA vowed to make the legislative process transparent, requiring a $60 \%$ majority from the 80-member council (i.e., 48 votes) to pass any legislation (Ellis, 2014). Division I member schools outside of the Power Five possess the ability to adopt or reject any rule changes crafted by the autonomy group, ensuring schools that cannot afford certain benefits are not put in a disadvantage financially (Solomon, 2014). 
One of the main issues discussed by the panel during the 2015 NCAA Convention focused on the scholarships of student-athletes and COA (Hosick, 2015). Following debates on the convention floor, the measure to provide athletes with a full COA financial package was passed by a vote of 79-1 (Sherman, 2015). Furthermore, non-Power Five conference leaders indicated they would also provide full COA scholarships to their athletes, while nonfootball Division I members noted they would consider them for some sports but not all (Fairbank, 2015).

The COA scholarship is calculated by each school as the difference between traditional educational expenses (i.e., room, board, books, tuition, etc.) and essential living expenses (i.e., clothing, laundry, insurance, etc.; Dodd, 2015). While the increased funding will benefit student-athletes, COA offers unique challenges in itself as each school does not calculate the amount similarly (MacLean \& NovyWilliams, 2015). Specifically, each school's COA calculation must factor the cost of living of the school's location. Thus, schools located in areas with higher food and transportation costs would provide higher COA than would schools with lower costs. For example, The Ohio State University offers $\$ 3,128$ per student-athlete, while Purdue University provides only $\$ 1,900$ (Dodd, 2015). Similarly, the University of Alabama offers $\$ 3,463$, while neighboring Auburn University provides over $\$ 5,000$ (New, 2015). The disparity in COA could be a major difference in recruiting efforts by these schools. However, the COA could also create unintended consequences in regards to tax liability.

\section{Income Taxes and IRC §117}

The U.S. Federal Income Tax was first established in February 1913 when the Sixteenth Amendment of the U.S. Constitution was ratified, granting Congress the power to levy taxes on the income of individuals (Kramer \& Previts, 2015). During the same year, Congress approved a tax on the net income of individuals and corporations through the Revenue Act of 1913, which established the first Internal Revenue Code (IRC). IRC $\$ 1$ and $\$ 11$ establish that the income of all individuals and corporations is subject to taxation regardless of its source (Williams \& Seifried, 2013). IRC §61(a) (2006a) generally defines gross income to include "all income charges from whatever source derived" (para. 1). These sources include compensation for services (i.e., fees, commissions, fringe benefits, etc.), business income, gains from property sales, interest and dividends, rent and royalties, alimony and separate maintenance payments, annuities, pensions, and income received in respect of a descendent or from an estate or trust.

However, the IRC does provide certain exclusions for both individuals and businesses to qualified money received from their taxable income. One of these exclusions is found in IRC $\S 117$ (2006b), which excludes any amount received in the form of a qualified scholarship by an individual for the purposes of obtaining a degree. Before $\$ 117$ was established in 1954 , the IRC did not include any specific provision to exclude scholarships from taxable income (Beck, 1996; Lee, 1985; Sharamitaro, 2004). Instead, the IRC of 1939 excluded scholarships and fellowship grants only if the scholarship could qualify as a gift (Stuart, 1976). If the scholarship could not classify as a gift, it would be deemed as compensation for services rendered and treated as income (Zwibelman, 1970). While this framework existed, 
a scholarship's taxability was determined on a case-by-case basis, and most were classified as tax-free gifts (Lee, 1985). Due to the uncertainty and confusion surrounding the classification, educational leaders from around the country called upon Congress to create a simplistic provision regarding the taxability of scholarships (Stuart, 1976; Zwibelman, 1970). According to Lee (1985), Congress analyzed several perspectives when considering changes to this tax policy. First, Congress wanted to support higher education by encouraging the use of financial aid while distinguishing between amounts disguised as salary or compensation (Mulleneaux, 1999). Congress also sought to reduce the volume of case-by-case litigation by providing a bright-line rule (Beck, 1996). Thus, Congress introduced IRC $\S 117$ to exempt scholarships from gross income.

After three decades of its implementation, the Tax Reform Act of 1986 (TRA 1986) amended $\$ 117$, limiting the exclusion of scholarships and grants to amounts received as a qualified scholarship (Cermignano \& Hargadon, 2000). According to Lazar (2010), a qualified scholarship includes amounts received by an individual that covers qualified tuition and related expenses. The term qualified tuition and related expenses refers to tuition and fees required for enrollment at an educational organization as well as any fees, books, supplies, and equipment required for courses (IRS, 2006b). Further, IRC $\$ 117$ also allows for any stipend received to cover disbursements for travel, research, clerical help, or equipment incident to the scholarship to be excluded from taxable income (Lee, 1985). However, any scholarship funding used for other expenses, such as room and board, is not excludable from gross income (IRS, 2014).

IRC $\$ 117$ (2006b) requires scholarship recipients to be candidates at an educational organization to qualify for the tax deduction. An educational organization is an institution that maintains a faculty and curriculum and has a regularly enrolled body of students in attendance where its educational activities take place (IRS, 2006c). Amounts paid to individuals to help them pursue their studies or conduct research are considered qualified scholarships if the primary purpose is to further the education of the recipient (Treas. Reg. 1.117-4(c)(2), 1986). This distinction requires students to attend a primary or secondary school or be an undergraduate or graduate student pursuing a degree at a college or university (Lazar, 2010).

Although $\$ 117$ as well as applicable Treasury Regulations offer tax exclusions for qualified scholarships, Treasury Regulation 1.117-4(c)(1) (2003) notes that the exclusion will be disqualified for taxpayers if the scholarship amount can be identified as compensation for past, present, or future services rendered or a payment for services that are subject to the direction or supervision of the grantor. Furthermore, a scholarship could be disqualified if the amount paid enables the recipient to conduct research or earn a degree for the benefit of the grantor (Lee, 1985). According to Sharamitaro (2004), students receiving funding for rendered services could exclude such amounts received from their gross income before TRA 1986 as long as all candidates performed the same services. However, the TRA 1986 repealed this exclusion, causing any payment or compensation received for services rendered to no longer be excludable from an individual's gross income (IRS, 2006b; Treas. Reg. 1-117-4(c)(2), 2003). Under the present tax code, the IRS clarifies that scholarships paid to recipients representing compensation for services rendered are not excludable from gross income. Thus, the primary objective of Treasury Regulation 1.117-4(c) (2003) is to identify circumstances where 
scholarship funding represents payments for services and disqualify individuals for the $\$ 117$ taxable income exclusion.

Several court cases have explored the application of Treasury Regulation 1.117-4 to scholarship recipients, including the seminal case of Bingler v. Johnson (1969). In this case, engineers employed through the Westinghouse Electric Corporation participated in an educational program designed to attract employees seeking further education and provide advanced training. As part of this program, the employees received an educational leave from their employment as well as a grant amounting to $80 \%$ of their annual salary to pursue their doctoral degrees in engineering (Zwibelman, 1970). The engineers participated in the work-study program in two distinct phases. First, the participants worked and attended classes part-time, with Westinghouse covering their tuition and expenses (Hoeflich, 1991). After the participants finished the coursework, Westinghouse provided time off from work as well as stipends to qualified employees so the participants could devote time to complete their dissertations. In return, the qualified employees completed progress reports on their degree status (Bingler v. Johnson, 1969).

The participating employees all filed federal tax returns with the Westinghouse stipends classified as scholarships (Hoeflich, 1991). However, the IRS rejected this claim and required the employees to report their stipends as taxable income, leading to a challenge in court (Zwibelman, 1970). At the district court level, the jury concluded the stipends received through the Westinghouse program constituted income and should be reported as such. On appeal, the Third Circuit Court of Appeals held that the regulations and instructions to the jury regarding Treasury Regulation 1.117-4 were invalid and that, as a matter of law, the scholarships were excludable to income. Furthermore, the Court of Appeals stated that "any reasonable stipend which comes within the common understanding of what constitutes a scholarship . . . is excluded from gross income" (Johnson v. Bingler, 1968, pp. 260-261). However, the appeal court decision proved to be erroneous as the Supreme Court held that taxpayers who provide services for their scholarship funding may not exclude the total amount from their gross income (Hoeflich, 1991; Zwibelman, 1970).

The Bingler v. Johnson (1969) decision legitimized Treasury Regulation $1.117-4$ by arguing that the definitions found in the regulation are prima facie proper with no substantial quid pro quo requirement from scholarship recipients. According to Hoeflich (1991), the U.S. Supreme Court stressed the importance of the quid pro quo test as students providing services in exchange for scholarships are not allowed to exclude their scholarships from gross income. Furthermore, the Court held that a payment cannot be classified as a scholarship when the recipient receives funding and, in return, provides a quid pro quo (Layman, 2011). As such, any payment received in exchange for performing a particular service will be treated by the IRS as compensation, instead of as a scholarship or grant (Larkins, 2000).

Since the Bingler decision, several court cases involving $§ 117$ and applicable Treasury Regulations have been heard in various U.S. Tax Courts. For example, Willie v. Commissioner (1971) involved an instructor who engaged in a training program that provided educators with helpful teaching and coping methods for children as schools were being integrated. The program was funded through the U.S. Department of Health, Education, and Welfare (HEW), and seminars were voluntary to all teachers and supervisors, which were held when schools were not in 
session. For his attendance, the instructor received $\$ 420$ on a per diem basis, which he did not report as taxable income. The IRS determined the instructor reported a $\$ 105$ deficiency in his federal income tax. The court agreed with the IRS as it found that the payments received from HEW represented compensation for services rendered, as the instructor's participation in the training program was primarily for the benefit of the school district (Willie v. Commissioner, 1971).

Similarly, Bonn v. Commissioner (1960) held that funds received by a physician in exchange for services provided to a Veterans' Administration (VA) hospital under a fellowship program constituted compensation for services instead of a scholarship or grant. The courts argued that the VA exists primarily for patient care, and a fellowship training program was a form of payment for providing services to help treat and care for patients. In Proskey v. Commissioner (1969), the court found that stipends received by a resident physician in exchange for his supervisory role over medical students and residents at a university hospital should be classified as compensation instead of as a fellowship grant.

In addition, Zolny v. Commissioner (1968) found that payments received by a doctoral candidate from his institution were taxable as compensation for services rendered as a research assistant. The court argued that the payments received by the student were compensation for services based on several factors, such as a 40-hour work week, the amount of compensation, the types of activities and level of supervision required for the activities, the disconnection between the student's research assistant responsibilities and his dissertation research, the disapproval of the student's application for a graduate fellowship, and the university's classification of the doctoral candidate as an employee (Zolny v. Commissioner, 1968). However, Smith v. Commissioner (1986) found that payments given to a graduate assistant while completing his/her master's degree should be classified as a scholarship. In its determination, the court found that the student worked on studies that would benefit only the student and not the university. The student also did not teach or conduct research on any university-led project during the funding period. As such, the court found no quid pro quo relationship (Smith v. Commissioner, 1986).

Based on these court cases, the IRS will treat academic scholarships as nontaxable income when a quid pro quo relationship cannot be determined (Hoeflich, 1991; Kisska-Schulze \& Epstein, 2016). However, if the IRS can determine that a payment was received in exchange for research, teaching, or other services, then a taxpayer must report the payment as taxable compensation. While this interpretation of $\S 117$ and Treasury Regulation 1.117-4 appear rudimentary based on the Bingler ruling, the application of the quid pro quo test is not as clear when considering the relationship between student-athletes and their respective universities.

\section{Athletic Grant-in-Aid}

Many scholars have analyzed the implementation of $\S 117$ and the Bingler decision in relation to student-athletes and their athletic scholarships (Cermignano \& Hargadon, 2000; Chin, 1993; Gould, Wong, \& Weitz, 2014; Hurst \& Pressly, 2000; Jensen, 1987; Kisska-Schulze \& Epstein, 2014, 2016; Lee, 1985; Nestel, 1992; Randall, 1972). According to Randall (1972), scholarships granted to student-athletes should be classified as taxable income based on Bingler's quid pro quo test. This rationale appears reasonable as student-athletes are required to maintain their eligibility in 
school to receive funding for tuition, room, and board (Cermignano \& Hargadon, 2000). While not a true pay-for-play agreement, issuing athletic scholarships for participation in college athletics constitutes a quid pro quo, making athletic scholarships fully taxable (Hoeflich, 1991; Hurst \& Pressly, 2000; Nestel, 1992).

However, the IRS does not pursue the taxation of athletic scholarships based on Revenue Ruling 77-263 (RR 77-263) (1977). Revenue rulings are official interpretations by the IRS and represent conclusions on the application of the code on pivotal facts discussed in the ruling (IRS, 2006d). The IRS issues revenue rulings when determining the tax consequences for a particular situation with the goal of interpretation uniformity (Rogovin \& Korb, 2009). Since $\S 117$ and Treasury Regulation 1.117-4 do not discuss athletic scholarships, the IRS introduced RR 77-263 to address this tax issue in 1977. Although it was issued before TRA 1986, Cermignano and Hargadon (2000) noted that the revenue ruling is still applicable to today's tax code.

RR 77-263 (1977) discusses scholarships awarded to student-athletes in line with the rules established by the NCAA and other college sport governing bodies. According to the rules, a student-athlete is eligible for an athletic scholarship when the following criteria are met:

(1) The student must be accepted at the university according to the admissions requirements applicable to all students at the university; (2) must be a full-time student; (3) scholarships are awarded by the agency of the university that is responsible for awarding scholarships to students in general; (4) once an athletic scholarship is awarded for a given academic year, it cannot be terminated in the event the student cannot participate in the athletic program, either because of injury or the student's unilateral decision not to participate; and (5) the student is not required to engage in any other activities in lieu of participation in a sport. (Rev. Rul. 77-263, 1977, para. 2)

The ruling also notes that the amount of the scholarship cannot exceed the expenses for tuition, fees, room, board, books, and supplies necessary for a student's studies. Should the scholarship exceed this total, then the funding amount must be reduced, or the student-athlete risks disqualification from participation in intercollegiate athletics.

While the ruling recognizes that student-athletes provide a form of service for their compensation, it also indicates that a university cannot require any particular activity from recipients, nor can the school cancel the scholarship due to injury or other form of nonparticipation besides academic ineligibility (Cermignano \& Hargadon, 2000). As such, a student-athlete is not required to include their athletic scholarship in their taxable income. However, Hoeflich (1991) argued that RR 77-263 is inconsistent, as "it reacts to the structure of an imaginary situation rather than the reality of modern college athletics" (p. 596). He argues that the ruling itself complies with the form of the law but not with its substance, due to an apparent quid pro quo relationship between the student-athlete and the university through an athletic scholarship, especially its duration. Several researchers support Hoeflich's (1991) argument in that the scholarship seems to no longer fit the 1977 RR 77-263 ruling due to how athletics are structured within our society today (Bennett, 2014; Berry, 2014; Hurst \& Pressly, 2000; Rovell, 2014; Lazar, 2010; Weaver, 2015). 
According to NCAA Bylaw 15.3.3.1.1 (2015), a member school can award athletic scholarships to student-athletes for a period of less than one academic year. This bylaw creates a renewable one-year award (up to five years) instead of a multiyear scholarship (Cermignano \& Hargadon, 2000). While a school cannot cancel a scholarship due to an injury, it can opt to not renew the award after its expiration (Hoeflich, 1991). Further, the NCAA (2015) allows its members to cancel financial aid to athletes if the recipient is declared ineligible for competition or voluntarily withdraws from the sport for personal reasons. Thus, a student-athlete could sign a letter of intent to participate in college athletics at a particular school, decide to no longer play in the sport, and lose his award based on that decision (Grimmet, 2014). While the bylaw is compliant with RR 77-263, the regulation "does not anticipate that the student-athlete's collegiate life will be split into a series of short-term contracts, each of which the student-athlete must fulfill to guarantee continuing aid" (Hoeflich, 1991, p. 596). Further, Nestel (1992) argued that the circumstances established in RR 77-263 are inconsistent when compared with the intercollegiate athletics business environment. The NCAA's big business perspective contradicts the IRS's conclusion that universities award athletic scholarships to aid recipients in pursuing their studies. Nestel (1992) also noted that the ruling does not comply with NCAA rules, as a university cannot terminate a scholarship upon the student-athlete's unilateral decision to withdraw from athletics. Both Hoeflich (1991) and Nestel (1992) believe the IRS's treatment of athletic scholarships fails to account for the NCAA bylaws as well as the spirit of $\S 117$.

Unfortunately, the courts have not directly addressed whether athletic scholarships should be considered taxable income (Davis, 1991; Hurst \& Pressly, 2000; Schinner, 1989). Instead, court cases involving student-athletes have only considered the issue tangentially. For example, the Colorado Supreme Court was unsure of how to classify the scholarship arrangement in University of Denver v. Nemeth (1953), which involved a college football player who was simultaneously an employee of the university and compensated for his services. According to Davis (1991), the athlete's employment was dependent on his football skills, and he would lose his job if he stopped playing. Due to this relationship, the athlete qualified for workers' compensation after sustaining injuries during a football practice (University of Denver v. Nemeth, 1953). In a similar case, the same Colorado Supreme Court denied workers' compensation benefits to the widow of a student-athlete killed during a football contest as no contractual obligation existed between the university and the deceased player (State Compensation Insurance Fund v. Industrial Commission, 1957). Although neither case addresses scholarships directly, these decisions acknowledge the existence of a quid pro quo relationship between student-athletes and universities as well as the classification of student-athletes as university employees.

Later cases would also engage in a similar struggle with this determination. In Taylor v. Wake Forest University (1972), a scholarship football player decided to forgo spring football practice to improve his academic standing. However, the student-athlete chose to no longer participate in football following the 1968 spring semester (Davis, 1991). In response, the university opted to terminate the studentathlete's scholarship due to his noncompliance. The North Carolina Court of Appeals agreed with the university's assessment, acknowledging the contractual agreement between a student-athlete and a school (Taylor v. Wake Forest University, 1972). 
Similarly, the Alabama Supreme Court found the student-athlete/institution relationship is contractual in nature (Gulf South Conference v. Boyd, 1979). Although this case focuses on the eligibility of a student-athlete following a transfer to another university (Davis, 1991), the court addressed the contract issue thus:

It should be noted that the relationship between a college athlete who accepts an athletic scholarship and the college which awards such an athletic scholarship is contractual in nature. The college athlete agrees to participate in a sport at the college, and the college in return agrees to give assistance to the athlete. The athlete also agrees to be bound by the rules and regulations adopted by the college concerning the financial assistance. (Gulf South Conference v. Boyd, 1979, p. 558)

Whereas these past cases established a contractual relationship between a student-athlete and university, the Indiana Supreme Court held no such relationship existed in Rensing v. Indiana State University Board of Trustees (1983). Like University of Denver v. Nemeth (1953), Rensing v. Indiana State (1983) addressed whether injured student-athletes qualify as university employees to receive workers' compensation benefits. Fixated primarily on workers' compensation, the court focused its attention on the scholarship offer itself and found that the student-athlete's acceptance of the scholarship did not elevate it to the level of an employment contract, as neither party considered the scholarship to be either pay or income. This conclusion was drawn from how the university, the NCAA, the IRS, and the student-athlete classified the scholarship as nontaxable, as the student-athlete did not report the scholarship payment amount on his income tax returns. Finally, the court concluded the IRS does not distinguish between athletic and academic scholarships, and scholarship recipients are not taxed on scholarship proceeds (Rev. Rul. 77-263, 1977). According to Ukeiley (1996), the court did not consider scholarship funding income if the proceeds were not considered reportable to the IRS. However, scholars believe the courts erred in this decision as they were primarily focused on the concept of amateurism (Davis, 1991; Nestel, 1992).

Despite these opinions, the IRS still holds the position that athletic scholarships qualify under $\$ 117$ and Treasury Regulation $1.117-4$. Specifically, IRS Commissioner John Koskinen drafted a letter to U.S. Senator Richard Burr (Republican, North Carolina) detailing the IRS's continued use of RR 77-263 (Koskinen, 2014). The letter was a response to Burr's inquiry regarding potential tax implications for athletic scholarships following the National Labor Relations Board (NLRB) decision to classify Northwestern University's football players as employees of the university under the National Labor Relation Act (Bennett, 2014). According to Koskinen (2014), the NLRB's decision to classify student-athletes as university employees has no bearing as to "whether the individual is an employee for federal tax purposes" (para. 2) and that the IRS abides by RR 77-263 in regard to athletic scholarships.

\section{Potential Tax Implications}

Despite assurance from Koskinen, the results from O'Bannon should cause the IRS to classify qualified scholarships as taxable income. According to KisskaSchulze and Epstein (2016), any future contractual agreements involving additional 
compensation should disqualify a student-athlete's athletic scholarship under RR 77-263. Specifically, the O'Bannon district decision refers to the student-athletes' share of revenue from the use of their names and likenesses as compensation (Spitzer, Ozmon, Coleman, Adams, \& Nuccio, 2014). Any payment of licensing revenue to student-athletes would be treated as taxable income regardless of whether it was paid directly to the student-athlete or placed into a trust account (Perlman \& Flores, 2014). Thus, when applying the quid pro quo test, it is difficult to distinguish what constitutes funding for educational purposes and compensation provided from NCAA licensing revenues (Berry, 2014).

Should the IRS deem athletic scholarships as taxable, student-athletes will be required to pay income taxes on their full scholarship amount. As of the 2014-15 academic year, the average athletic scholarship offered by NCAA Division I Football Bowl Subdivision members was $\$ 18,273$ for male athletes and $\$ 17,341$ for female athletes ("College Football \& Scholarship," n.d.). Using this average, the current research provides provide the example of an 18-year-old male 5-star football recruit who receives a full athletic scholarship to a major university in the State of Louisiana. The scholarship he receives covers tuition, fees, books, room and board, academic-related supplies, transportation, and other similar items in exchange for his participation on the football team. Thus, a quid pro quo is established, making the scholarship fully taxable. Table 1 provides a summary of the potential tax impact on athletic scholarships.

Before income taxes can be calculated, certain items must be defined to determine the correct tax liability. First, an individual must provide his/her filing status as this status determines whether a tax return is required, the standard deduction amount, and the amount of taxes owed (IRS, 2015a). These statuses include single, married filing jointly, married filing separately, head of household, and qualifying widow(er) with dependent child. Using the example from earlier, the athlete's filing status is single (IRS, 2015b). Next, an individual must determine if someone can claim him/her as a dependent. This declaration is important as it provides individuals with an exemption to help reduce their taxable income. ${ }^{1}$ However, if an individual can be claimed on someone else's tax return as a dependent, then that individual cannot claim a personal exemption (IRS, 2015a, 2015b). Common examples of dependents include parents claiming their children or an elderly parent. Regardless if an individual can be claimed as a dependent, the individual is still required to file a tax return if he/she earns gross income above the established floor (IRS, 2015a). ${ }^{2}$ Table 1 shows the effects on the example athlete as both a dependent and an independent for tax purposes. Finally, it is important for individuals to consider the state they reside in regard to income taxes levied on earned income during the tax year (Kisska-Schulze \& Epstein, 2014; Pogroszewski, 2009). The 50 U.S. states maintain differing policies in regard to income taxation (Kahn, 2015). ${ }^{3}$ The recruit example would be a resident of Louisiana as he will generate his gross income within the State of Louisiana.

With these factors in mind, one can estimate the tax liability for a studentathlete. His gross income during the 2015 tax year would be $\$ 18,273$. Assuming the athlete does not qualify for any deductions (e.g., educator expenses, student loan interest, alimony paid, etc.) before adjusted gross income (AGI), his AGI would be $\$ 18,273$. One can also assume the student-athlete would claim the standard deduction instead of an itemized deduction (e.g., medical expenses, charitable 


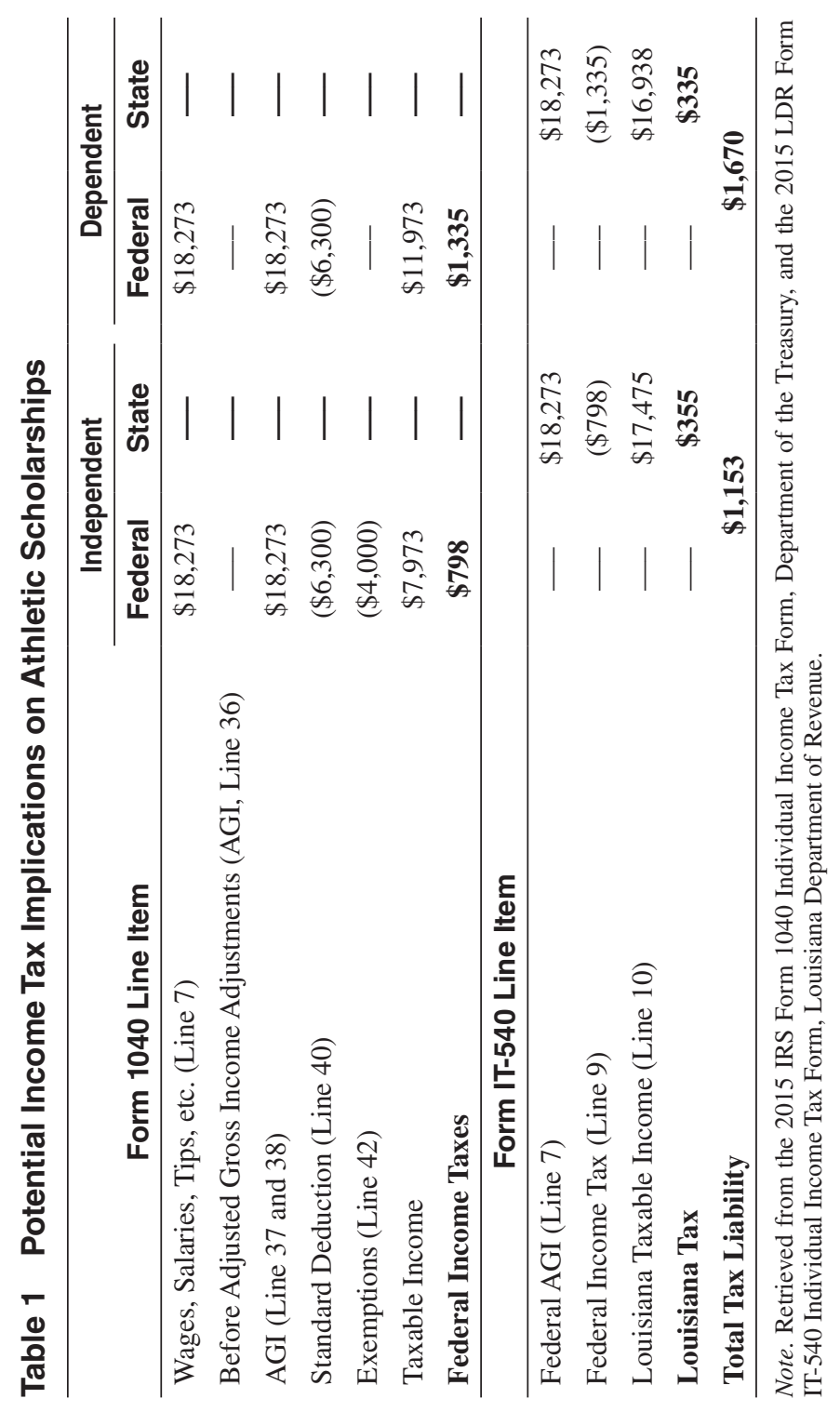


contributions, mortgage interest, etc.). Thus, the athlete would be able to deduct $\$ 10,300$ from his AGI, leaving him with $\$ 7,973$ in taxable income. Because the athlete's filing status is single, he would be subject to the single tax rate schedule, which charges taxable income up to $\$ 9,225$ a $10 \%$ tax and gradually increases to $39.6 \%$ based on the total amount of taxable income (IRS, 2015a). The athlete would be taxed a federal income tax of $\$ 798$ for his athletic scholarship. In addition, the State of Louisiana would also charge taxes on the athlete's scholarship (Louisiana Department of Revenue [LDR], 2015). Following a deduction for his federal tax expense, the athlete would be taxed $\$ 355$ on his Louisiana taxable income of $\$ 17,475$. If the athlete were claimed as a dependent by his parents, the tax structure would change significantly for the worse, as he could no longer claim the $\$ 4,000$ personal exemption. This removal would cause his taxable income to increase to $\$ 11,973$, putting him in the $15 \%$ tax bracket and generating $\$ 1,335$ in federal income taxes. While his state income tax liability would decrease to $\$ 335$, the athlete would be charged more in income taxes in this scenario.

\section{Other Considerations}

Other potential factors to consider are payroll taxes under the Federal Insurance Contributions Act (FICA). Taxes under FICA are composed of old-age, survivors, and disability insurance taxes (i.e., social security) and the hospital insurance tax (i.e., Medicare; IRS, 2016). An employer is responsible for withholding these taxes from an employee's wages, which are subject to FICA taxes regardless of employee age or whether the employee receives social security benefits. The social security rate is $6.2 \%$ each for the employer and employee, while the Medicare rate is $1.45 \%$ (IRS, 2016). If a student-athlete's scholarship is considered taxable, he or she would also be charged payroll taxes of $\$ 1,398,{ }^{4}$ reducing the wages net of taxes even further.

Finally, a common argument regarding paying student-athletes focuses on the classification of student-athletes as either employees or independent contractors (McCormick \& McCormick, 2006). An independent contractor is an individual who is in an independent trade, business, or profession in which he or she offers services to the general public. While this discussion is important for classification purposes, the independent contractor classification will only cause the student-athlete to pay for the employer portion of the FICA payroll taxes, making his overall tax liability increase (IRS, 2016). However, the student-athlete should be treated as an employee since there is an established quid pro quo (Cermignano \& Hargadon, 2000).

\section{Conclusion}

The impact stemming from O'Bannon as well as the Power Five schools' decision to provide COA scholarships could create unintended consequences to the student-athletes these situations are attempting to benefit. This issue does not have a definitive answer, as the courts have never ruled on this issue. As such, it would be essential for the Supreme Court to hear any future case to define the classification of student-athletes as employees or students. Based on past decisions, it appears the NCAA member schools and the student-athletes engage in a quid pro quo relationship as services (i.e., participating in intercollegiate athletics) are 
being exchanged for compensation (i.e., athletic scholarship and cost of attendance). Because of this relationship, athletic scholarships should not be classified as qualified scholarships under RR 77-263. This change would make an athletic scholarship fully taxable and create a substantial tax burden for student-athletes at both the federal and state levels.

Furthermore, the differentiation in cost of attendance would raise significant issues in both taxation and athlete recruiting. Schools located in states that do not levy an income tax may have an unfair recruiting advantage over states that do levy income taxes, as the student-athlete could receive financial support through tax savings. This variation could impact the competitive balance the NCAA strives to maintain within its divisions. Finally, if student-athletes are required to pay income taxes on their athletic scholarships, they may not be able to cover the additional expenses created from the taxation. As such, it may be the parents of the studentathletes who are tasked with covering the tax burden, meaning that a scholarship to fund higher education would be more financially detrimental than beneficial.

\section{Notes}

1. In 2015 , an individual could receive $\$ 6,300$ in standard deduction and $\$ 4,000$ in personal exemptions for each dependent he or she could claim on his or her tax return.

2. The gross income floor for individuals filing single and under the age of 65 in 2015 was $\$ 10,300$.

3. Seven U.S. states do not have an income tax: Alaska, Florida, Nevada, South Dakota, Texas, Washington, and Wyoming. In addition, New Hampshire and Tennessee residents pay income taxes only on dividends and investment income.

4. FICA Tax Liability to Student: $(\$ 18,273 \times 6.2 \%)+(\$ 18,273 \times 1.45 \%)=\$ 1,398$.

\section{References}

Beck, R. (1996). Loan repayment assistance programs for public-interest lawyers: Why does everyone think they are taxable? New York Law School Law Review, 40, 251-310.

Bennett, B. (2014, March 27). Northwestern players get union vote. ESPN. Retrieved from http://espn.go.com/

Berry, K. (2014, April 13). College athletics could be sacked with high taxes on scholarships. CPA Practice Advisor. Retrieved from http://www.cpapracticeadvisor.com/

Berkowitz, S. (2015, September 30). Federal appeals court upholds ruling NCAA violates antitrust laws. USA Today. Retrieved from http://www.usatoday.com/

Berkowitz, S. (2016, March 15). O'Bannon plaintiffs ask Supreme Court to take case. USA Today. Retrieved from http://www.usatoday.com/

Berkowitz, S., \& Perez, A. (2016). Supreme Court will not consider the Ed O'Bannon antitrust case against NCAA. USA Today. Retrieved from https://www.usatoday.com/story/ sports/college/2016/10/03/supreme-court-ed-obannon-ncaa-antitrust-case/91462090/

Bingler v. Johnson et al., 394 U.S. 741 (1969).

Bonn v. Commissioner of Internal Revenue, 34 T.C. 64 (1960).

Cermignano, G., \& Hargadon, J. (2000). The U.S. federal tax consequences of athletic scholarships: Is the recipient an employee? Effect on gross income and dependency status. Sport Management Review, 3, 185-197. doi:10.1016/S1441-3523(00)70085-4

Chin, C. (1993). Illegal procedures: The NCAA's unlawful restraint of the student-athlete. Loyola of Los Angeles Law Review, 26, 1213-1250. 
College football \& scholarship opportunities (n.d.). ScholarshipStats.com. Retrieved from http://www.scholarshipstats.com/football.html

Davis, R. (1991). The courts and athletic scholarships. North Dakota Law Review, 67, 163-196.

Dodd, D. (2015, February 27). Players about to get paid as money changes game in college athletics. CBS Sports. Retrieved from http://www.cbssports.com/

Ellis, Z. (2014, August 7). Breaking down NCAA's approval of Power Five autonomy. SI.com. Retrieved from http://www.si.com/

Fairbank, D. (2015, February 14). Outside of Power 5 conference, mixed reaction to NCAA legislation on extra benefits. Daily Press. Retrieved from http://www.dailypress.com/

Grimmet, E. (2014). NCAA amateurism and athletics: A perfect marriage or a dysfunctional relationship? An antitrust approach to student-athlete compensation. Touro Law Review, 30, 823-860.

Gould, W., Wong, G., \& Weitz, E. (2014). Full court press: Northwestern University, a new challenge to the NCAA. Loyola of Los Angeles Entertainment Law Review, 35, 1-66.

Gulf South Conference v. Boyd, 369 So.2d 553 (1979).

Kahn, C. (2015, January 13). State with no income tax: Better or worse? Bankrate. Retrieved from http://www.bankrate.com/finance/taxes/state-with-no-income-tax-better-orworse-1.aspx

Hoeflich, A. (1991). The taxation of athletic scholarships: A problem of consistency. University of Illinois Law Review, 1991, 581-618.

Hosick, M. (2014, August 7). Board adopts new Division I structure: Student-athletes will vote at every governance level. NCAA. Retrieved from http://www.ncaa.org/about/ resources/media-center/news/board-adopts-new-division-i-structure

Hosick, M. (2015, January 18). Autonomy schools adopt cost of attendance scholarship: College athletes' viewpoints dominate business session discussions. NCAA. Retrieved from http://www.ncaa.org/about/resources/media-center/autonomy-schools-adoptcost-attendance-scholarships

Hurst, T., \& Pressly, J. (2000). Payment of student-athletes: Legal and practical obstacles. Villanova Sports \& Entertainment Law Journal, 7, 55-82.

Internal Revenue Service. (2006a). Internal Revenue Code (§61(a)). Washington, DC: Author. Retrieved from https://www.law.cornell.edu/uscode/text/26/61\#.ViEg5UZQRAM

Internal Revenue Service. (2006b). Internal Revenue Code (\$117). Washington, DC: Author. Retrieved from https://www.law.cornell.edu/uscode/text/26/117

Internal Revenue Service. (2006c). Internal Revenue Code (\$170(b)(1)(A)(ii)). Washington, DC: Author. Retrieved from https://www.law.cornell.edu/uscode/text/26/170

Internal Revenue Service. (2006d). Internal Revenue Code (\$601.601(d)(2)(i)(a)). Washington, DC: Author. Retrieved from https://www.law.cornell.edu/cfr/text/26/601.601

Internal Revenue Service. (2014). Tax benefits for education (Publication 970). Washington, DC: Author. Retrieved from https://www.irs.gov/pub/irs-pdf/p970.pdf

Internal Revenue Service. (2015a). 2015 Form 1040 instructions. Washington, DC: Author. Retrieved from https://www.irs.gov/pub/irs-pdf/i1040gi.pdf

Internal Revenue Service. (2015b). Exemptions, standard deduction, and filing information (Publication 501). Washington, DC: Author. Retrieved from https://www.irs.gov/pub/ irs-pdf/p501.pdf

Internal Revenue Service. (2016). (Circular E), Employer's tax guide. (Publication 15). Washington, DC: Author. Retrieved from https://www.irs.gov/pub/irs-pdf/p15.pdf

Jensen, E. (1987). Taxation, the student athlete, and the professionalization of college athletics. Utah Law Review, 1987, 35-58.

Johnson et al. v. Bingler, 396 F.2d 258 (3rd Cir., 1968).

Kisska-Schulze, K., \& Epstein, A. (2014). "Show me the money!" Analyzing the potential state tax implications of paying student-athletes. Virginia Sports and Entertainment Law Journal, 14, 13-49. 
Kisska-Schulze, K., \& Epstein, A. (2016). Northwestern, O'Bannon, and the future: Cultivating a new era for taxing qualified scholarships. Akron Law Review, 49, 771-812.

Kramer, S., \& Previts, G. (2015). Ivar Kreuger and IMCO: A case of taxation of fictitious income. The International Journal of Accounting, 50, 300-315. doi:10.1016/j. intacc.2015.07.004

Koskinen, J. (2014, April 9). [Letter to U.S. Senator Richard Burr]. Internal Revenue Service (UIL No: 117.00-00), Washington, DC: Author. Retrieved from https://www.irs.gov/ pub/irs-wd/14-0016.pdf

Larkins, E. (2000). Coming to America: International students face a labyrinth of income tax issues. Connecticut Journal of International Law, 15(1-2), 47-94.

Law et al. v. NCAA, 134 F.3d 1010 (10th Cir., 1998).

Layman, J. (2011). Forgiven but not forgotten: Taxation of forgiven student loans under the income-based repayment plan. Capital University Law Review, 39, 131-159.

Lazar, S. (2010). Schooling Congress: The current landscape of the tax treatment of higher education expenses and a framework for reform. Michigan State Law Review, 2010(4), 1047-1128.

Lee, R. (1985). The taxation of athletic scholarships: An uneasy tension between benevolence and consistency. University of Florida Law Review, 37, 591-614.

Lodge, A. (2016). Who's afraid of the big bad NCAA? . . The Ed O'Bannon v. NCAA decision's impact on the NCAA's amateurism model. The Journal of Corporation Law, 41, 775-793.

Louisiana Department of Revenue. (2015). 2015 Form IT-540i instructions. Baton Rouge, LA: Author.

MacLean, P., \& Novy-Williams, E. (2015, September 30). U.S. college athletes get school costs paid but no cash. Bloomberg. Retrieved from http://www.bloomberg.com

McCormick, R.A., \& McCormick, A.C. (2006). The myth of the student-athlete: The college athlete as an employee. Washington Law Review (Seattle, Wash.), 81, 71-157.

Mulleneaux, N. (1999). The failure to provide adequate higher education tax incentives for lower-income individuals. Akron Tax Journal, 14(1), 27-42.

NCAA v. Board of Regents of the University of Oklahoma et al., 468 U.S. 85 (1984).

Nestel, D. (1992). Athletic scholarships: An imbalance of power between the university and the student-athlete. Ohio State Law Journal, 53, 1401-1420.

New, J. (2015, August 12). More money . . if you can play ball. Inside Higher Ed. Retrieved from https://www.insidehighered.com

O'Bannon v. National Collegiate Athletic Association, 7 F.Supp.3d 955 (N.D. Ca. 2014).

O'Bannon v. National Collegiate Athletic Association, 14-16601, (9th Cir., 2015).

Perlman, J., \& Flores, A. (2014, December 2). Students, athletes-and taxpayers? Accounting Today. Retrieved from http://www.accountingtoday.com/

Pogroszewski, A. (2009). When is a CPA as important as your ERA? A comprehensive evaluation and examination of state tax issues on professional athletes. Marquette Sports Law Review, 19, 395-417.

Proskey v. Commissioner of Internal Revenue, 51 T.C. 918 (1969).

Randall, G. (1972). Athletic scholarships and taxes: Or a touchdown in taxes. Gonzaga Law Review, 7, 297-309.

Rensing v. Indiana State University Board of Trustees, 444 N.E.2d 1170 (1983).

Revenue Ruling 77-263, 1977-31 I.R.B. (1977).

Rogovin, M., \& Korb, D. (2009). The four 4's revisited: Regulations, rulings, reliance and retroactivity in the 21st century: A view from within. Taxes: The Tax Magazine, 87(8), 21-66.

Rovell, D. (2014, March 27). Players could get big tax bill. ESPN. Retrieved from: http:// www.espn.com/

Sanserino, M. (2014, April 6). College athletes union raises tax, discrimination questions. The Pittsburgh Post-Gazette. Retrieved from http://www.post-gazette.com/ 
Schinner, M. (1989). Touchdowns and taxes: Are athletic scholarships merely disguised compensation? American Journal of Tax Policy, 8, 127-165.

Sharamitaro, M. (2004). The federal tax system and treatment of scholarship for graduate students: Should scholarships be taxed? Saint Louis University Law Journal, 48, 1501-1530.

Sherman, M. (2015, January 17). Full cost of attendance passes 79-1. ESPN. Retrieved from http://espn.go.com/

Smith v. Commissioner, 52 T.C.M. 691 (1986).

Solomon, J. (2014, August 7). NCAA adopts new Division I model giving Power 5 autonomy. CBS Sports. Retrieved from http://www.cbssports.com/

Spitzer, A., Ozmon, K., Coleman, D., Adams, D., \& Nuccio, M. (2014, September 15). Game on! Recent legal developments and tax issues for collegiate athletics. Ropes \& Gray. Retrieved from https://www.ropesgray.com/newsroom/alerts/2014/September/ Game-On-Recent-Legal-Developments-and-Tax-Issues-for-Collegiate-Athletics.aspx

State Compensation Insurance Fund v. Industrial Commission, 314 P.2d 288 (Colo. 1957).

Stuart, W. (1976). Tax status of scholarship and fellowship grants: Frustration of legislative purpose and approaches to obtain the exclusion granted by congress. Emory Law Journal, 25, 357-392.

Treasury Regulation $\$ 1.117-4$ (2003).

Taylor v. Wake Forest University, 191 S.E. 2 d 379 (1972).

Tutka, P. (2016). An ideal-type through innovation diffusion: Recording the construction history of football stadiums in the National Collegiate Athletic Association division I football bowl subdivision (Unpublished doctoral dissertation). Louisiana State University, Baton Rouge, LA.

Ukeiley, S. (1996). No salary, no union, no collective bargaining: Scholarship athletes are an employer's dream come true. Seton Hall Journal of Sports Law, 6, 167-222.

University of Denver v. Nemeth, 257 P.2d 423 (Colo. 1953).

Weaver, A. (2015). New policies, new structure, new problems? Reviewing the NCAA's autonomy model. Elon Law Review, 7, 551-570.

Williams, D., \& Seifried, C. (2013). The taxing postseason: The potential impact of unrelated business income taxation on college football bowl organizers. Journal of Legal Aspects of Sport, 23, 72-90. doi:10.1123/jlas.23.2.72

Willie v. Commissioner of Internal Revenue, 57 T.C. 383 (1971).

Zolny v. Commissioner, 49 T.C. 389 (1968).

Zwibelman, M. (1970). Taxability of scholarships and fellowships. Missouri Law Review, 35, 393-404. 